\title{
PELATIHAN MANAJEMEN SUMBER DAYA MANUSIA DAN PENDAMPINGAN APLIKASI TEKNIS MARKETPLACE SEBAGAI STRATEGI BAGI UMKM DESA KERINJING DI MASA PANDEMI
}

\author{
Lina Dameria Siregari1), Wita Farla1), Yuliansyah M.Diah'1), Nia Meitisari'1), Hera Febria Mavilinda') \\ 1)Jurusan Manajemen, Fakultas Ekonomi, Universitas Sriwijaya, Palembang, Sumatera Selatan, Indonesia \\ Corresponding author : Lina Dameria Siregar \\ E-mail : linadameria@fe.unsri.ac.id
}

Diterima 29 November 2021, Disetujui 04 Desember 2021

\begin{abstract}
ABSTRAK
Pengelolaan dan manajemen bisnis dalam usaha mikro, kecil, dan menengah (UMKM) masih menjadi permasalahan yang seringkali diabaikan oleh kebanyakan para pelaku UMKM. Masalah ini disebabkan karena masih minimnya pengetahuan dan kemampuan manajerial tentang bisnis yang dimiliki oleh SDM di UMKM tersebut. Tujuan dari dilaksanakannya pengabdian masyarakat ini adalah untuk memberikan solusi tas masalah yang dihadapi oleh mitra binaan, khususnya di UMKM Desa Kerinjing, Kabupaten Ogan Ilir, Sumatera Selatan. Fokus utama dalam pengabdian ini adalah memberikan berbagai pendampingan dan pelatihan dalam kaitannya dengan prinsip dasar manajemen bisnis yang baik, diantaranya yaitu tentang pemberdayaan dan peningkatan kompetensi SDM UMKM melalui pelatihan aplikasi marketplace. Disrupsi ekonomi digital dan adanya pandemi Covid-19 merupakan peluang yang seharusnya dapat dimanfaatkan oleh para pelaku usaha kecil untuk beralih ke bisnis online. Hal ini diupayakan untuk seiring sejalan dengan program pemerintah yang berupaya mewujudkan sebanyak 30juta UMKM untuk beralih ke bisnis online pada tahun 2024. Adapun khalayak sasaran yang menjadi mitra dalam pengabdian masyarakat ini adalah para pelaku UMKM di Desa Kerinjing, Kecamatan Tanjung Raja, Kabupaten Ogan Ilir. Metode dalam pelaksanaan kegiatan pengabdian ini adalah ceramah, tutorial aplikasi, dan diskusi.
\end{abstract}

Kata kunci: manajemen; marketplace; SDM; UMKM; desa kerinjing.

\begin{abstract}
Business management in micro, small and medium enterprises (MSMEs) is a problem that is often ignored by most MSME entrepreneurs. This problem is caused by the lack of knowledge and managerial skills about the business owned by human resources in the MSMEs. The purpose of this community service is to provide solutions to problems faced by partners, especially in SMEs in Desa Kerinjing, Ogan llir, South Sumatra. The main focus in this service is to provide various assistance and training related to the basic principles of good business management, including the empowerment and improvement of MSME human resources competencies through marketplace application training. Disruption of the digital economy and the Covid-19 pandemic are opportunities that should be used by small business entrepreneurs to move to online business. This is in accordance with the program that has been launched by the government, namely "30 million MSMEs go digital by 2024". The target audience who are partners in this community service are MSME entrepreneurs in Desa Kerinjing, Ogan llir, South Sumatra. The methods in implementing this service activity are lectures, application tutorials, and discussions.
\end{abstract}

Keywords: management; marketplaces; human resources; MSMEs; desa kerinjing.

\section{PENDAHULUAN}

Di banyak negara berkembang seperti Indonesia, keberadaan UMKM menjadi sangat penting dan potensial. Keberadaan UMKM saat ini mampu mendorong terciptanya lapangan kerja bagi masyarakat lokal. UMKM adalah salah satu bentuk usaha yang terbukti masih dapat survive dan bertahan menghadapi terpuruknya perekonomian masa pandemi (Rohim \& Kurniawan, 2017).
Sektor usaha mikro, kecil dan menengah (UMKM) mempunyai peranana yang sangat penting dalam menopang perekonomian negara. UMKM mampu menyerap pengangguran yang ada menjadi tenaga kerja sehingga mengurangi kemiskinan dan merupakan sarana berwirausaha bagi rakyat (Ezizwita \& Tri Sukma, 2019). Permasalahan lain yang dihadapi UMKM adalah masalah penjualan, kurangnya inovasi dan daya saing, 
serta minimnya pemanfaatan teknologi bagi bisnisnya (Ariani \& Utomo, 2017).

Desa Kerinjing merupakan salah satu dari desa binaan Universitas Sriwijaya. Penduduk Desa Kerinjing memiliki mata pencaharian dari hasil pertanian dan perkebunan serta dari usaha-usaha rumah tangga (home industry) seperti usaha penjahit pakaian, usaha warung sembako, usaha pembuatan kerupuk kemplang. Potensi lokal ini telah lama dikembangkan di Desa Kerinjing dan mayoritas didominasi oleh ibu-ibu desa setempat.

Pengabdian kepada masyarakat ini dilakukan dengan metode yaitu berupa penyuluhan dan pelatihan tentang prinsip dasar manajemen bisnis khususnya manajemen SDM karena pada hakikatnya untuk mencapai tujuan sehingga perlu dibina, dilatih dan ditingkatkan keterampilan dan wawasannya. Tujuan lainnya dari pengabdian ini adalah untuk memberikan pelatihan dan pendampingan kepada para ibuibu pelaku UMKM Desa Kerinjing tentang aplikasi marketplace, suatu media teknologi yang aman untuk bertransaksi (secure payment), mudah digunakan (user friendly), serta dapat diakses secara gratis sehingga dengan menggunakan marketplace dapat memperluas akses pasar sehingga usahanya mampu bertahan di masa pandemi.

\section{Marketplace}

Marketplace adalah salah satu aplikasi media penjualan online berbasis website. Pada dasarnya, marketplace mempunyai konsep yang sama dengan pasar tradisional yaitu tempat bertemunya antara pembeli dan penjual secara virtual. Pada awalnya, kelahiran aplikasi marketplace ditandai dengan munculnya Amazon di Amerika Serikat pada tahun 1995.

Khusus di Indonesia sendiri, telah sering kita jumpai dalam transaksi sehari-hari berbagai aplikasi marketplace yang sangat populer diantaranya yaitu Shopee, Tokopedia, Bukalapak, Blibli, dan masih banyak lagi (Widyayanti, 2019).

Disrupsi ekonomi digital dan adanya pandemi covid-19 seharusnya menjadi momen bagi UMKM untuk beralih ke bisnis online. Adanya perubahan gaya belanja msyarakat yang berubah dari offline menjadi online, hendaknya ditandai sebagai momen perubahan dan kebangkitan kembali UMKM.

Dari hasil survei yang dilakukan oleh Katadata Insight Center (KIC) bertajuk "MSME Study Report 2021 yang berjudul Peran Marketplace bagi UMKM". Survei ini telah dilaksanakan terhadap sebanyak 392 UMKM di Indonesia selama periode 24 Maret-9 April 2021. Hasil survei menunjukkan bahwa sebanyak 77\% marketplace membantu UMKM memasarkan produk. Sekitar $72 \%$ responden menyukai promo gratis ongkir, promo cashback, dan diskon harga. Sebanyak 69\% responden menyatakan marketplace adalah aplikasi yang aman dan $66 \%$ responden senang dengan kemudahan fitur aplikasi tersebut.

\section{METODE}

Khalayak sasaran yang menjadi mitra dalam pengabdian masyarakat ini adalah para pelaku UMKM di Desa Kerinjing, Kecamatan Tanjung Raja, Kabupaten Ogan Ilir. Adapun jumlah peserta kegiatan pengabdian masyarakat ini sebanyak 25 orang. Pelaku usaha tersebut meliputi usaha-usaha rumah tangga (home industry) seperti usaha penjahit pakaian, usaha warung sembako, dan usaha pembuatan kerupuk kemplang di Desa Kerinjing. Pelaksanaan kegiatan pengabdian kepada masyarakat ini telah terselenggara secara offline dengan tata cara menggunakan metode pelatihan dan pendampingan dalam kurun waktu \pm 2 bulan.

\section{HASIL DAN PEMBAHASAN}

Pertemuan dengan khalayak sasaran pengabdian berjudul "Pelatihan Manajemen Sumber Daya Manusia dan Pendampingan Aplikasi Teknis Marketplace sebagai Strategi bagi UMKM" kepada masyarakat pelaku UMKM di UMKM di Desa Kerinjing, beralamat di Kecamatan Tanjung Raja, Kabupaten Ogan Ilir telah dilaksanakan pada beberapa rangkaian tahap-tahapan kegiatan yaitu:

\section{1) Pra survei dan pemetaan awal}

Kegiatan pengabdian pada masyarakat ini diawali dengan pra survei dan pemetaan awal yang dilakukan dengan melakukan survei lokasi yang menjadi khalayak sasaran Pengabdian yaitu pada pelaku UMKM Desa Kerinjing, yang beralamat di Kecamatan Tanjung Raja, Kabupaten Ogan Ilir.

Diskusi dan wawancara awal (interview) dengan Kepala Desa Kerinjing serta identifikasi situasi dan diskusi atas permasalahanpermasalahan spesifik yang dihadapi mitra binaan yaitu pelaku UMKM Desa Kerinjing, yang beralamat di Kecamatan Tanjung Raja, Kabupaten Ogan Ilir. 


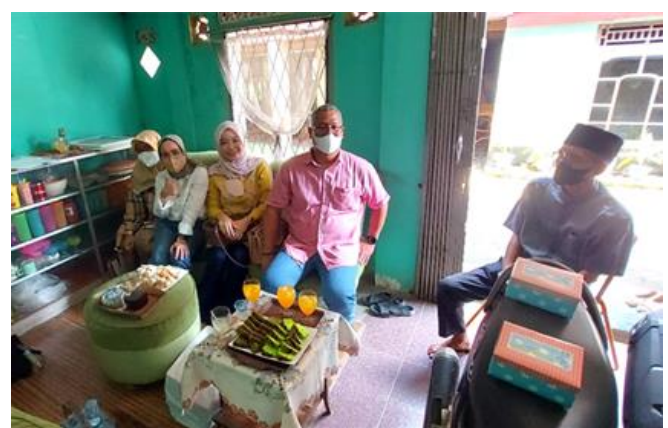

Gambar 1. Diskusi dengan Kepala Desa

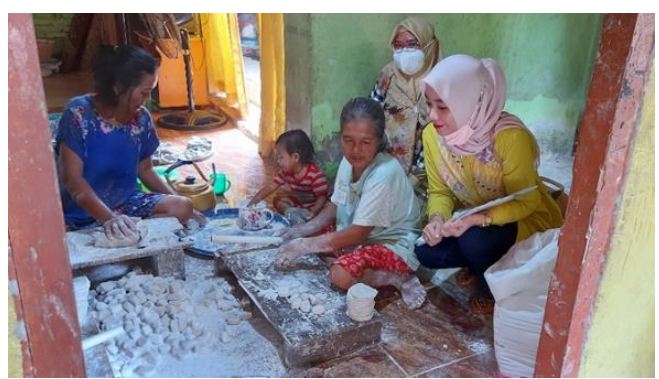

Gambar 2. Diskusi dengan Pelaku UMKM Desa Kerinjing

\section{2) Pendampingan dan Pelatihan}

Dalam kegiatan pendampingan dan pelatihan ini, dilakukan melalaui metode ceramah/pelatihan, diskusi, tutorial aplikasi yang digunakan, dan diskusi. Pelatihan tentang konsep ilmu manajemen serta pelatihan dan pendampingan tentang aplikasi marketplace yang disampaikan oleh tim dosen yang berperan sebagai panitia pelaksana dalam kegiatan pengabdian ini.

Adapun materi yang telah disampaikan kepada peserta pengabdian masyarakat ini antara lain mengenai:

1. Peningkatan pemahaman mitra tentang ilmu manajemen.

2. Peningkatan pemahaman mitra tentang manajemen usaha UMKM.

3. Pemahaman tentang tata cara penggunaan aplikasi marketplace dan strategi meningkatkan penjualan dengan aplikasi marketplace.

4. Mitra UMKM diberikan materi mengenai pengelolaan SDM UMKM, serta tips dan trik sukses memanfaatkan aplikasi marketplace.

5. Mitra UMKM diberikan kesempatan untuk mendiskusikan permasalahan dan kendala yang berkaitan dengan pengelolaan SDM UMKM dan strategi bisnis UMKM nya.

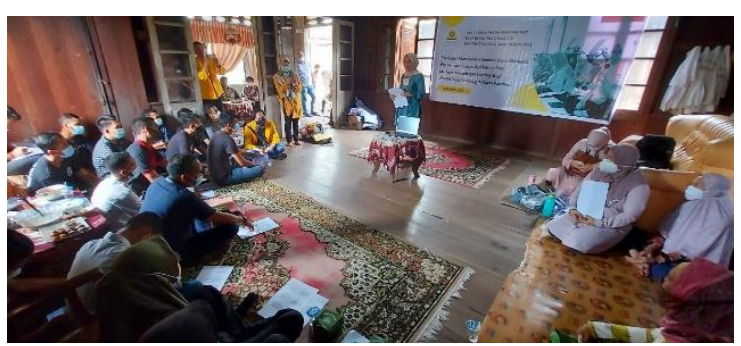

Gambar 3. Kegiatan Pelatihan dan Pendampingan

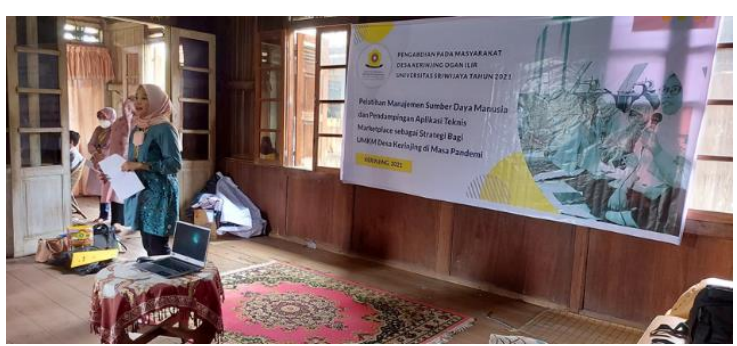

Gambar 4. Kegiatan Pelatihan dan Pendampingan

\section{3) Monitoring dan Evaluasi}

Hasil evaluasi dalam kegiatan "Pelatihan Manajemen Sumber Daya Manusia dan Pendampingan Aplikasi Teknis Marketplace sebagai Strategi bagi UMKM" ini yaitu sebagian besar peserta sangat antusias dalam mengikuti pelatihan dan pendampingan.

Monitoring dilaksanakan dengan membandingkan kondisi mitra saat sebelum dan sesudah diberikan pelatihan dalam kegiatan pengabdian ini. Monitoring program dilakukan dengan melihat perkembangan dan peningkatan usaha mitra.

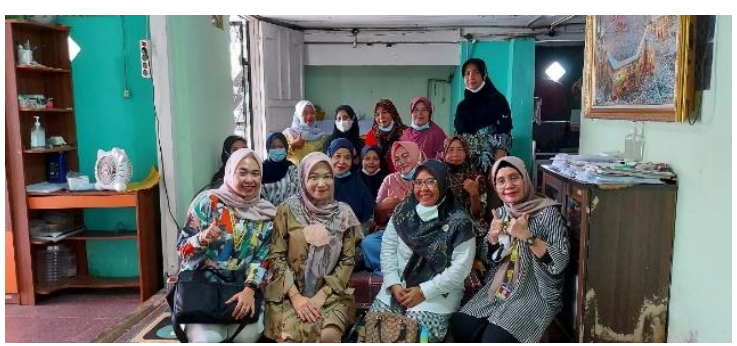

Gambar 5. Monitoring kepada Mitra Binaan

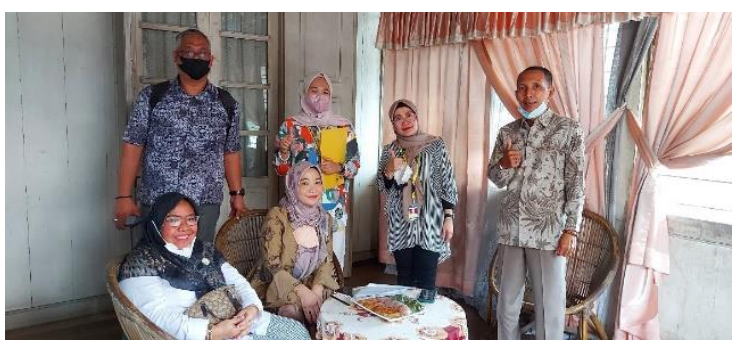

Gambar 6. Evaluasi dengan Kepala Desa

\section{SIMPULAN DAN SARAN}

Sebagian besar pelaku UMKM di Desa

Kerinjing, Kecamatan Tanjung Raja, Kabupaten Ogan Ilir, belum memahami 
kemampuan manajemen organisasi, keterampilan manajerial (SDM) pada UMKM, dan strategi bisnis UMKM. Pelaku UMKM di Desa Kerinjing, Kecamatan Tanjung Raja, Kabupaten Ogan Ilir, mayoritas belum memahami hal-hal yang berkaitan dengan keterampilan pengelolaan SDM UMKM, strategi bisnis UMKM, dan aplikasi marketplace. Saran yang dapat diberikan adalah dilakukan pelatihan lanjutan mengenai prinsip, dasar, dan prosedur pengelolaan manajemen SDM UMKM di Desa Kerinjing, Kecamatan Tanjung Raja, Kabupaten Ogan Ilir, karena peserta kegiatan cukup antusias terhadap program pelatihan dan pendampingan. Dengan adanya pelatihan lanjutan, diharapkan dapat meningkatkan pengetahuan dan kemampuan manajemen organisasi dan strategi bisnis bagi UMKM di Desa Kerinjing, Kecamatan Tanjung Raja, Kabupaten Ogan Ilir. Hal tersebut dikarenakan minat pelaku usaha yang cukup tinggi untuk mendapatkan bimbingan dan binaan dalam pemanfaatan media online dan aplikasi marketplace.

\section{UCAPAN TERIMAKASIH}

Kegiatan Pengabdian kepada Masyarakat ini didanai oleh Dana PNBP Universitas Sriwijaya. Penulis mengucapkan terima kasih kepada Rektor Universitas Sriwijaya, Lembaga Penelitian dan Pengabdian Masyarakat Universitas Sriwijaya, Dekan Fakultas Ekonomi, Bapak Faisal Kimi selaku Kepala Desa Kerinjing, Ogan Ilir, Sumatera Selatan, dan segenap masyarakat binaan pelaku UMKM di Desa Kerinjing, serta seluruh Panitia pelaksana atas terselenggaranya kegiatan pengabdian kepada masayarakat ini.

\section{DAFTAR RUJUKAN}

Ariani, A., \& Utomo, M. N. (2017). Kajian Strategi Pengembangan Usaha Mikro Kecil Dan Menengah (Umkm) Di Kota Tarakan. Jurnal Organisasi Dan Manajemen, 13(2), 99-118. https://doi.org/10.33830/jom.v13i2.55.2 $\underline{017}$

Ezizwita, E., \& Tri Sukma, M. M. E. Y. F. (2019). Pelatihan Manajemen Usaha Dan Peningkatan Promosi Untuk Pengembangan UMKM Makanan Ringan. Prosiding Konferensi Nasional Pengabdian Kepada Masyarakat Dan Corporate Social Responsibility (PKMCSR), 2, 1197-1204. https://doi.org/10.37695/pkmcsr.v2i0.5 12

Katadata Insight Center. MSME Study Report. 2021.
Rohim, A., \& Kurniawan, I. (2017). Manajemen Usaha Dan Produksi Pada Usaha Mikro, Kecil Dan Menengah (UMKM) Di Desa Carang Wulung Wonosalam. Comvice: Journal of Community Service, 1(1), 23-28. https://doi.org/10.26533/comvice.v1i1. 116

Widyayanti, E. R. (2019). Pengaruh Marketplace Terhadap Peningkatan Pendapatan Pada Ukm (Studi Pada Ukm Di Daerah Istimewa Yogyakarta). Jurnal Optimum, 9(1), 1-14. 